\title{
Absolute Quantification of Prion Protein (90-231) Using Stable Isotope-Labeled Chymotryptic Peptide Standards in a LC-MRM AQUA Workflow
}

\author{
Robert Sturm, ${ }^{1}$ Gloria Sheynkman, ${ }^{1}$ Clarissa Booth, ${ }^{2}$ Lloyd M. Smith, ${ }^{1}$ \\ Joel A. Pedersen, ${ }^{2,3}$ Lingjun $\mathrm{Li}^{1,4}$ \\ ${ }^{1}$ Department of Chemistry, University of Wisconsin, Madison, WI 53705, USA \\ ${ }^{2}$ Molecular and Environmental Toxicology Center, University of Wisconsin, Madison, WI 53705, USA \\ ${ }^{3}$ Department of Soil Science, University of Wisconsin, Madison, WI 53706, USA \\ ${ }^{4}$ School of Pharmacy, University of Wisconsin, Madison, WI 53705, USA
}

\begin{abstract}
Substantial evidence indicates that the disease-associated conformer of the prion protein $\left(\mathrm{PrP}^{\mathrm{TSE}}\right)$ constitutes the etiologic agent in prion diseases. These diseases affect multiple mammalian species. PrP ${ }^{T S E}$ has the ability to convert the conformation of the normal prion protein $\left(\operatorname{PrP}^{\mathrm{C}}\right)$ into a $\beta$-sheet rich form resistant to proteinase $\mathrm{K}$ digestion. Common immunological techniques lack the sensitivity to detect PrPTSE at subfemtomole levels, whereas animal bioassays, cell culture, and in vitro conversion assays offer higher sensitivity but lack the high-throughput the immunological assays offer. Mass spectrometry is an attractive alternative to the above assays as it offers high-throughput, direct measurement of a protein's signature peptide, often with subfemtomole sensitivities. Although a liquid chromatography-multiple reaction monitoring (LC-MRM) method has been reported for PrP ${ }^{T S E}$, the chemical composition and lack of amino acid sequence conservation of the signature peptide may compromise its accuracy and make it difficult to apply to multiple species. Here, we demonstrate that an alternative protease (chymotrypsin) can produce signature peptides suitable for a LC-MRM absolute quantification (AQUA) experiment. The new method offers several advantages, including: (1) a chymotryptic signature peptide lacking chemically active residues (Cys, Met) that can confound assay accuracy; (2) low attomole limits of detection and quantitation (LOD and LOQ); and (3) a signature peptide retaining the same amino acid sequence across most mammals naturally susceptible to prion infection as well as important laboratory models. To the authors' knowledge, this is the first report on the use of a non-tryptic peptide in a LC-MRM AQUA workflow.
\end{abstract}

Key words: Protein quantification, Multiple reaction monitoring (MRM), AQUA, Prion, Stable isotope labeled reference for absolute quantitation, Chymotrypsin

Electronic supplementary material The online version of this article (doi:10.1007/s13361-012-0411-1) contains supplementary material, which is available to authorized users.

Correspondence to: Joel Pedersen; e-mail: joelpedersen@wisc.edu, Lingjun Li; e-mail:1li@pharmacy.wisc.edu

\section{Introduction}

T ransmissible spongiform encephalopathies (TSEs) or 1 prion diseases are a family of fatal neurodegenerative diseases that affect humans (Creutzfeldt-Jakob disease, CJD)

Received: 26 February 2012

Revised: 8 May 2012

Accepted: 10 May 2012

Published online: 20 June 2012 
and a variety of farmed and free-ranging mammals, including cattle (bovine spongiform encephalopathy, BSE), sheep and goats (scrapie), North American members of the deer family (chronic wasting disease, CWD), and mink (transmissible mink encephalopathy, TME) [1-6]. Prion diseases are unique among protein misfolding disorders in that they are transmissible. Sheep scrapie and CWD appear unique among prion diseases in that epizootics can be sustained through horizontal transmission and that an environmental reservoir of infectivity can contribute to transmission [4, 7-15]. Chronic wasting disease in captive and free-ranging animals and BSE in domestic cattle have caused substantial agricultural, economic, and social impacts. Bovine spongiform encephalopathy has transmitted to humans in the form of variant $\mathrm{CJD}$, raising concern about the potential for CWD to cross the human species barrier [16-20]. The pathogenic prion protein, denoted as $\mathrm{PrP}^{\mathrm{TSE}}$, can induce conformational changes in the normal, benign cellular form of the protein, $\operatorname{PrP}^{\mathrm{C}}$, leading to disease propagation and accumulation of $\operatorname{PrP}^{\mathrm{TSE}}$ [21]. The cellular and pathogenic isoforms of the prion protein possess identical primary sequences and covalent post-translational modifications, and differ only in their conformation [21-27]. Circular dichroism and infrared spectroscopy studies have indicated that conversion of $\operatorname{PrP}^{\mathrm{C}}$ to $\operatorname{PrP}^{\mathrm{TSE}}$ is accompanied by a dramatic increase $\beta$-sheet content $[28,29]$. The differences in secondary and higher order structures of $\operatorname{PrP}^{\mathrm{C}}$ and $\operatorname{PrP}^{\mathrm{TSE}}$ confer on them profoundly different biophysical properties. $\operatorname{PrP}^{\mathrm{C}}$ is susceptible to proteolysis, is soluble in water and detergents, and exists as a monomer. In contrast, $\mathrm{PrP}^{\mathrm{TSE}}$ is partially resistant to proteolysis, insoluble in water and non-denaturing detergents, and has a propensity to aggregate. Differences in protease resistance is frequently used to discriminate between the two conformers. Treatment of $\mathrm{PrP}^{\mathrm{TSE}}$ with proteinase $\mathrm{K}(\mathrm{PK})$ yields the PK-resistant core of the molecule, denoted $\operatorname{PrP}^{27-30}$ because of the position to which it migrates in SDS-PAGE. In contrast, similar treatment of $\operatorname{PrP}^{\mathrm{C}}$ leads to the generation of many small peptide fragments [21]. Therefore, PK-treatment of $\operatorname{PrP}^{\mathrm{C}}$ or $\operatorname{PrP}^{\mathrm{TSE}}$ yields distinct peptide products, enabling their detection and quantification.

Detection and quantification of $\operatorname{PrP}^{\mathrm{TSE}}$ remain challenging. An intracerebral infectious dose of $\operatorname{PrP}^{\mathrm{TSE}}$ for hamsters has been estimated to contain $\sim 10^{4}$ to $10^{5}$ molecules $(\sim 0.02$ to 0.2 amol) $[30,31]$. The most widely employed methods to detect prions and $\operatorname{PrP}^{\mathrm{TSE}}$ are animal bioassay and immunological assays. Animal bioassay is the most direct technique to measure prion infectivity and is considered the "gold standard" for prion detection, but is animal-intensive, time-consuming, expensive, and generally limited to rodent-adapted prion strains, or requires the use of transgenic mice expressing the prion protein of interest [32]. Immunologic assays such as Western blotting, enzyme-linked immunosorbent assays, and a conformation-dependent immunoassay are commonly used in prion research but have limits of detection (LOD) from 20 to $0.1 \mathrm{pmol}$ [33-40]. Other classes of prion detection methods are in vitro conversion assays and cell culture methods. Protein misfolding cyclic amplification (PMCA) is a powerful prion conversion assay that exploits the ability of $\operatorname{PrP}^{\mathrm{TSE}}$ to convert
$\operatorname{PrP}^{\mathrm{C}}$ to a PK-resistant form in a manner conceptually similar to the polymerase chain reaction [41-43]. Many amplification/ conversion cycles can be performed to increase $\mathrm{PrP}^{\mathrm{TSE}}$ levels 10- to $10^{7}$-fold prior to detection [41]. A drawback of this method is that amplification of $\operatorname{PrP}^{\mathrm{TSE}}$ can take several days to achieve ultrasensitivity, stringent conditions are required to prevent false positive results [44], and levels of $\mathrm{PrP}^{\mathrm{TSE}}$ are not directly measured. Addition of polymeric beads to PMCA reactions has recently been shown to improve the robustness of the method $[45,46]$. Cell culture-based methods have recently been reported for several economically important species [47, 48].

Mass spectrometry-based methods using stable isotopelabeled standards (SIS) for absolute quantification (AQUA) represent an attractive alternative to the prion detection methods mentioned above. The AQUA method involves introducing a known concentration of a SIS peptide to a protein digest that yielded the same unlabeled peptide. Peptide abundances of the two peptides (SIS and native) are then measured by liquid-chromatography with multiple reaction monitoring (LC-MRM), and the concentration of the targeted protein is calculated using a calibration curve. This method allows sub-femtomole quantification of proteins in complex mixtures $[49,50]$.

A LC-MRM assay was recently reported for the detection and quantitation of $\operatorname{PrP}^{\mathrm{TSE}}$ in Syrian hamster brain homogenate [51, 52]. A potential drawback to the reported method is that the signature tryptic peptide used for quantitation contains two chemically reactive residues (Cys, Met) that could compromise assay accuracy. Furthermore, although a high degree of sequence identity exists across mammalian species, the primary structure differs slightly in each [53]. This would require that the tryptic SIS peptide to be revalidated for additional species [54], adding expense to the lab.

Our work explores the use of alternative proteases to produce a peptide suitable for LC-MRM AQUA assays of prion protein. A suitable AQUA peptide is defined here as (1) lacking chemically active residues (Cys, Met) that can compromise the accuracy of the assay, (2) providing subfemtomole LOD and LOQ, and (3) identical across multiple mammalian species susceptible to natural prion disease or used as laboratory models. Many LC-MRM AQUA publications mention in passing that proteases other than trypsin could, in principle, be used to produce a peptide suitable for a quantification assay [50,55], but to the authors' knowledge, accounts of other enzymes being utilized for this type of assay have not been published. Thus, our work reports the first application of a non-tryptic peptide in a LCMRM AQUA workflow.

\section{Experimental}

\section{Chemicals}

Iodoacetamide (IAA), $\beta$-octyl glucopyranoside (BOG), $\alpha$ cyano-4-hydroxycinnamic acid (CHCA), thermolysin, tri- 
fluoroacetic acid (TFA), and hydrofluoric acid (HF) were purchased from Sigma-Aldrich (St. Louis, MO, USA). Ammonium bicarbonate, formic acid (FA), and heavy AQUA peptides RPV $\left[{ }^{13} \mathrm{C}_{5},{ }^{15} \mathrm{~N}\right] \mathrm{DQY}, \quad \mathrm{YPPV}\left[{ }^{13} \mathrm{C}_{5},{ }^{15} \mathrm{~N}\right]$ DQY, and FL $\left[{ }^{13} \mathrm{C}_{6},{ }^{15} \mathrm{~N}_{2}\right]$ NPWEK were supplied by Thermo Fisher Scientific (Waltham, MA, USA). Dithiothreitol (DTT) and sequence-grade modified trypsin were purchased from Promega (Madison, WI, USA). Bovine chymotrypsin and glutamic acid-C (Glu-C) were purchased from Princeton Separations (Adelphia, NJ, USA). Bovine recombinant prion protein (bovine rPrP) was purchased from Abcam (Cambridge, MA, USA). Syrian hamster recombinant prion protein (hamster $\mathrm{rPrP}^{90-231}$ ) was supplied by Jena Bioscience (Jena, Germany). Sterile filtered mouse serum was purchased from Equitech-Bio, Inc. (Kerrville, TX, USA). The $18 \mathrm{M} \Omega \cdot \mathrm{cm}$ water used in these experiments was obtained from a Milli-Q purification system (Millipore, Bedford, MA, USA). The LC-MS grade solvents acetonitrile (ACN) and water for the Waters nanoAcquity UPLC (Milford, MA, USA) were purchased from Burdick and Jackson (Muskegon, MI, USA). The Optima grade solvents ACN and water for the Eksigent Ultra 2D UPLC (Dublin, CA, USA) were purchased from Fisher Scientific (Fair Lawn, NJ, USA).

\section{Chymotrypsin, Trypsin, Glu-C, and Thermolysin Digestions for AQUA Peptide Identification}

Bovine $\operatorname{rPrP}\left(5 \mu \mathrm{L}, 1 \mu \mathrm{g} \cdot \mu \mathrm{L}^{-1}\right)$ was combined with $15 \mu \mathrm{L}$ $0.01 \%$ BOG (wt/vol) and sonicated for $5 \mathrm{~min}$ in an ultrasonic bath. Cysteine residues in bovine $\mathrm{rPrP}$ were reduced with $10 \mu \mathrm{L} 10 \mathrm{mM}$ DTT prepared in buffer A (25 mM ammonium bicarbonate in $0.01 \%$ BOG [wt/vol]) for $1 \mathrm{~h}$ at $37{ }^{\circ} \mathrm{C}$. After cooling to room temperature, cysteines were alkylated with $40 \mu \mathrm{L} 10 \mathrm{mM}$ IAA in darkness for $1 \mathrm{~h}$ at room temperature. Alkylation was quenched by incubation in $20 \mu \mathrm{L} 10 \mathrm{mM}$ DTT for $15 \mathrm{~min}$ at room temperature. All digestions were performed under the manufacturer's suggested conditions: chymotrypsin (1:50 enzyme:protein ratio, $\left.30{ }^{\circ} \mathrm{C}, 9 \mathrm{~h}\right)$; Glu-C $(1: 20$ enzyme:protein ratio, $\left.25{ }^{\circ} \mathrm{C}, 16 \mathrm{~h}\right)$; thermolysin $(1: 25$ enzyme:protein ratio, $\left.37^{\circ} \mathrm{C}, 24 \mathrm{~h}\right)$; and trypsin $(1: 50$ ratio, $37{ }^{\circ} \mathrm{C}, 16 \mathrm{~h}$ ). Each digest was quenched by addition of $2.5 \mu \mathrm{L} 10 \%$ (vol/vol) $\mathrm{FA}_{(\mathrm{aq})}$, desalted with C18 OMIX pipette tip (Agilent Technologies, Santa Clara, CA, USA), and concentrated by speedvac (Thermo Scientific, Waltham, MA, USA). Dried eluent was resuspended in $60 \mu \mathrm{L} 50 \%$ $\mathrm{ACN} / 0.1 \% \mathrm{TFA}_{(\mathrm{aq})}(\mathrm{vol} / \mathrm{vol})$ and stored at $4{ }^{\circ} \mathrm{C}$ until analysis on a Bruker amaZon ETD ion trap (Billerica, MA, USA) mass spectrometer.

\section{Optimization of Chymotrypsin Digestion Time}

Three $5 \mu \mathrm{L}$ aliquots of hamster $\operatorname{rPrP}^{90-231}\left(1 \mu \mathrm{g} \cdot \mu \mathrm{L}^{-1}\right)$ were reduced, alkylated, and chymotrypsinized as described above except the total volume was diluted to $100 \mu \mathrm{L}$. At desired time points, $20 \mu \mathrm{L}$ aliquots of each digest were removed, and $0.5 \mu \mathrm{L}\left(0.1 \mu \mathrm{g} \cdot \mu \mathrm{L}^{-1}\right)$ fresh chymotrypsin was added to each digestion tube. The chymotryptic digestion in each aliquot was quenched by addition of $1 \mu \mathrm{L} 10 \% \mathrm{FA}_{(\mathrm{aq})}$ (vol/vol), and the reaction was desalted with C18 OMIX pipette tip and concentrated by speedvac. Concentrated samples were reconstituted in $100 \mu \mathrm{L} 3 \% \mathrm{ACN} / \mathrm{FA}_{(\mathrm{aq})}(\mathrm{vol} /$ vol) containing SIS peptide YRPVDQY. Subsequent serial dilutions yielded final analyte and internal standard concentrations of $5 \mathrm{fmol} \cdot \mu \mathrm{L}^{-1}$ and $10 \mathrm{fmol} \cdot \mu \mathrm{L}^{-1}$, respectively. Each time-point sample was analyzed in triplicate using a Bruker Autoflex III TOF/TOF and AB SCIEX 5500 QTRAP (Foster City, CA, USA) mass spectrometer.

\section{Hamster $\operatorname{rPr} P^{90-231}$ Quantification}

Three $2 \mu \mathrm{L}$ aliquots of hamster $\operatorname{rrP}^{90-231}\left(1 \mu \mathrm{g} \cdot \mu \mathrm{L}^{-1}\right)$ were reduced, alkylated and chymotrypsinized (vide supra). Chymotryptic digestion was allowed to proceed for $9.5 \mathrm{~h}$ before $2.5 \mu \mathrm{L} 10 \% \mathrm{FA}_{(\mathrm{aq})}(\mathrm{vol} / \mathrm{vol})$ was added to quench the reaction. A $5 \mu \mathrm{L}$ aliquot of the digest was placed in $45 \mu \mathrm{L}$ $0.1 \% \mathrm{FA}_{(\mathrm{aq})}(\mathrm{vol} / \mathrm{vol})$ containing $11.1 \mathrm{fmol} \cdot \mu \mathrm{L}^{-1} \mathrm{SIS}$ peptides RPVDQY and YRPVDQY, desalted with C18 OMIX pipette tip, and concentrated by speedvac. Concentrated samples were reconstituted in $200 \mu \mathrm{L} 3 \% \mathrm{FA}_{(\mathrm{aq})}(\mathrm{vol} /$ vol). Each digest was analyzed in triplicate on an AB SCIEX 5500 QTRAP mass spectrometer.

\section{Qualitative Mass Spectrometry}

Bovine rPrP peptide fragments produced by tryptic, chymotryptic, thermolytic, and Glu-C digestions were identified by nanoESI-direct infusion $\left(300 \mathrm{~nL} \cdot \mathrm{min}^{-1}\right)$ into a Bruker amaZon ETD ion trap mass spectrometer. In addition, digestions were analyzed by nanoLC-MS/MS using an Eksigent Ultra 2D UPLC. Mobile phase A was water in $0.1 \% \mathrm{FA}_{(\mathrm{aq})}(\mathrm{vol} / \mathrm{vol})$, and mobile phase $\mathrm{B}$ was $\mathrm{ACN}$. Samples were introduced into the system by a $5 \mu \mathrm{L}$ injection onto an Agilent Technologies Zorbax 300 SB-C18 $5 \mu \mathrm{m}, 5 \times$ $0.3 \mathrm{~mm}$ trap cartridge (Santa Clara, CA, USA) at a flow rate of $5 \mu \mathrm{L} \cdot \mathrm{min}^{-1}$ of $95 \%$ mobile phase A for $5 \mathrm{~min}$. Peptides were separated on a $3 \mu \mathrm{m}$ Waters Atlantis dC18 $75 \mu \mathrm{m} \times$ $150 \mathrm{~mm}$ column (Milford, MA, USA) with a $40 \mathrm{~min}$ gradient from $5 \%$ to $35 \%$ mobile phase $\mathrm{B}$ at a flow rate of $250 \mathrm{~nL} \cdot \mathrm{min}^{-1}$ and column temperature of $30{ }^{\circ} \mathrm{C}$. Electrospray emitter tips were prepared in house from $75 \mu \mathrm{m}$ i.d., $360 \mu \mathrm{m}$ o.d. capillary tubing (Polymicro Technologies, Phoenix, AZ, USA) using a Sutter P-2000 laser capillary puller (Novato, CA, USA).

Capillary voltage was set to $-1300 \mathrm{~V}$, end plate offset voltage was $-500 \mathrm{~V}$, dry gas flow was $4.0 \mathrm{~L} \cdot \mathrm{min}^{-1}$, and dry gas temperature was $125^{\circ} \mathrm{C}$. MS data were acquired from 300 to $1700 \mathrm{~m} / \mathrm{z}$ in enhanced resolution mode $\left(8100 \mathrm{~m} / \mathrm{z} \mathrm{s}^{-1}\right)$ with a target mass of $700 \mathrm{~m} / \mathrm{z}$ and trap drive level of $100 \%$. $\mathrm{CAD} \mathrm{MS}^{2}$ spectra were manually collected with a $1-\mathrm{V}$ MS/ 
MS fragmentation amplitude, and smart fragmentation was set at $30 \%$ to $300 \%$.

Bovine rPrP peptide fragments produced by chymotryptic digestion in the timed digestion experiment were identified using a Bruker autoflex III MALDI TOF/TOF mass spectrometer. For this analysis, equal volumes $(0.5 \mu \mathrm{L})$ of reconstituted digest and matrix solution, consisting of $5 \mathrm{mg}$ CHCA dissolved in $1 \mathrm{~mL} 50 \% \mathrm{ACN} / 0.1 \% \mathrm{TFA}_{(\mathrm{aq})}$ (vol/ vol), were mixed on a ground-steel plate and allowed to dry. Mass spectra were acquired in reflectron positive ion mode with a $200 \mathrm{~Hz}$ repetition rate averaging 500 laser shots.

In silico tryptic, chymotryptic, thermolytic, and Glu-C digestions of bovine and hamster $\mathrm{rPrP}$ were performed using MS-Digest tool from the Protein Prospector suite (http:// prospector.ucsf.edu, v. 5.9.2) developed by UCSF. Carbamidomethylation was set as a static modification, methionine oxidation was selected as a variable modification, the minimum peptide length equaled five, peptide mass ranged from 300 to $2500 \mathrm{~m} / \mathrm{z}$, and multiple charged ions were reported in the algorithm's output. Prion protein amino acid alignment was carried out with Jalview software (http://www.jalview.org/download.html) [56, 57] and the clustalW alignment algorithm [58]. Protein sequences were from uniprot/swissprot knowledgebase (http://www.uniprot.org/help/uniprotkb).

\section{Quantitative Mass Spectrometry}

LC-MRM experiments were performed with a Waters nanoAcquity UPLC connected online with an AB SCIEX 5500 QTRAP equipped with a nanospray III ion source. Initial experiments to manually optimize instrument response for YRPVDQY and FLNPWEK were done by direct infusion. The two peptides $\left(2.5 \mathrm{pmol} \cdot \mu \mathrm{L}^{-1}\right.$ in $50 \% \mathrm{ACN} /$ $\left.0.1 \% \mathrm{FA}_{(\mathrm{aq})}[\mathrm{vol} / \mathrm{vol}]\right)$ were infused into the mass spectrometer at $500 \mathrm{~nL} \cdot \mathrm{min}^{-1}$. A precursor scan was used to confirm the presence of analyte ions in the mass spectrometer, and a product ion scan was used to determine the dominant $\mathrm{MS}^{2}$ fragment peaks. Curtain gas, ionspray voltage, ion source gas 1 , interface heater temperature, and ESI emitter position were optimized for the precursor signal, while the declustering potential (DP), entrance potential (EP), collision energy (CE), and collision cell exit potential were optimized for each precursor/product ion MRM transition to obtain maximum analyte/MRM intensity while maintaining stable electrospray intensity. Instrument settings for RPVDQY were optimized using Skyline software (https://skyline.gs.washington.edu, v. 0.7) developed by the MacCoss Lab [59].

For LC-MRM experiments curtain gas was set to $20 \mathrm{psi}$, collision gas was medium, ionspray voltage was $2300 \mathrm{~V}$, ion source gas 1 was set to $16 \mathrm{psi}$, and interface heater temperature was $150{ }^{\circ} \mathrm{C}$. UPLC elution solvents were: A $\left(0.1 \% \mathrm{FA}_{(\mathrm{aq})}[\mathrm{vol} / \mathrm{vol}]\right)$ and $\mathrm{B}\left(\mathrm{ACN} / 0.1 \% \mathrm{FA}_{(\mathrm{aq})}[\mathrm{vol} / \mathrm{vol}]\right)$. Samples resuspended in $3 \% \mathrm{ACN} / 0.1 \% \mathrm{FA}_{(\mathrm{aq})}(\mathrm{vol} / \mathrm{vol})$ were loaded onto a self-packed C18 trap cartridge (Phenom- enex Jupiter C18 $5 \mu \mathrm{m}, 100 \mu \mathrm{m} \times 70 \mathrm{~mm}$; ) at a flow rate of $2.00 \mu \mathrm{L} \cdot \mathrm{min}^{-1}$ solvent A over $10.0 \mathrm{~min}$. Samples were eluted from a self-packed reversed-phase column (Phenomenex Jupiter C18 $5 \mu \mathrm{m}, 75 \mu \mathrm{m} \times 120 \mathrm{~mm}$ ) integrated with a HF etched $8 \mu \mathrm{m}$ ESI emitter tip (Sutter Instrument P-2000, Novato, CA, USA) using an 11 min linear gradient from $3 \%$ to $35 \%$ solvent $\mathrm{B}$ at a flow rate of $500 \mathrm{~nL} \cdot \mathrm{min}^{-1}$. Solvent B was raised to $70 \%$ to elute remaining peptides, and the column was re-equilibrated for $10 \mathrm{~min}$ in $3 \%$ solvent B prior to injection of the next sample. The mass spectrometer was operated in MRM mode, alternating between detection of YRPVDQY (ion transitions $\mathrm{m} / \mathrm{z}$ $470.7^{+2}$ to $759.3^{+1}\left[\mathrm{~b}_{6}\right], 470.7^{+2}$ to $631.3^{+1}\left[\mathrm{~b}_{5}\right], 470.7^{+2}$ to $182.1^{+1}\left[\mathrm{y}_{1}\right]$ ), and YRPV $\left[{ }^{13} \mathrm{C}_{5},{ }^{15} \mathrm{~N}\right] \mathrm{DQY}$ (ion transitions $\mathrm{m} / \mathrm{z} 473.7^{+2}$ to $765.3^{+1}\left[\mathrm{~b}_{6}\right], 473.7^{+2}$ to $637.3^{+1}\left[\mathrm{~b}_{5}\right]$, $473.7^{+2}$ to $182.1^{+1}\left[\mathrm{y}_{1}\right]$ ), RPVDQY (ion transitions $\mathrm{m} / \mathrm{z}$ $389.2^{+2}$ to $596.3^{+1}\left[\mathrm{~b}_{5}\right], 389.2^{+2}$ to $468.3^{+1}\left[\mathrm{~b}_{4}\right], 389.2^{+2}$ to $182.1^{+1}\left[\mathrm{y}_{1}\right]$ ), $\mathrm{RPV}\left[{ }^{13} \mathrm{C}_{5},{ }^{15} \mathrm{~N}\right] \mathrm{DQY}$ (ion transitions $\mathrm{m} / \mathrm{z}$ $392.2^{+2}$ to $602.3^{+1}\left[b_{5}\right], 392.2^{+2}$ to $474.3^{+1}\left[b_{4}\right], 392.2^{+2}$ to $\left.182.1^{+1}\left[\mathrm{y}_{1}\right]\right)$. Q1 and Q3 were operated in unit resolution mode, and dwell time for each transition was set to $40 \mathrm{~ms}$. Quantification was performed with the IntelliQuan quantification algorithm of Analyst 1.5.1 software (AB SCIEX) using default parameters. Calibration curves, proteolysis time, and digest accuracy graphs were prepared using Graphpad Prism (v. 5.0) software.

\section{Results and Discussion}

\section{Identifying a Non-Tryptic Peptide for AQUA Quantification of $\operatorname{Pr} P^{T S E}$}

We simulated digestion of the proteinase K-resistant core of Syrian hamster and bovine $\operatorname{PrP}^{\mathrm{TSE}}$ by 13 proteases in silico with Protein Prospector's MS-Digest algorithm: trypsin, chymotrypsin, Lys C, Lys N, pepsin, Arg C, Asp N, Asp C, DE-N, Glu-C, Tyr-C, thermolysin, and Pro-C. Chymotrypsin, Glu-C, and thermolysin showed promise in that they produced peptides in silico that met our first criterion for a suitable AQUA peptide (Supplemental Table 1): lack of chemically active residues (Cys, Met) that can compromise assay accuracy (Supplemental Figure 1). Chymotrypsin cleaves peptide bonds predominantly on the carboxyl side of Tyr, Phe, and Trp. Glu-C cleaves peptide bonds at the carboxyl side of Glu residues. Thermolysin is predicted to cleave peptides at the N-terminal side of hydrophobic amino acid residues Leu, Ile, Phe, Val, Ala, and Met [60].

After identifying proteases that may potentially produce a peptide meeting our first criterion, trypsin, chymotrypsin, Glu-C, and thermolysin digestions were performed according to manufacturers' instructions. Desalted proteolytic digests were directly infused into a Bruker amaZon ETD ion trap mass spectrometer and also subjected to nanoLCMS/MS analysis to experimentally determine which peptides predicted in in silico digests warranted further consideration for a quantitative assay. 
Trypsin was included in the initial screening of proteases because it had previously been used for prion quantification $[51,52,54,61]$. Supplemental Figure 1 demonstrates that bovine $\mathrm{PPrP}$ tryptic peptide VVEQMCITQYQR was observed in both its normal (a) and sulfoxide forms (b) during nanoLC-MS/MS analysis. Supplemental Figure 1c shows that the SIS peptide VVEQMCTTQYQK was also observed in its normal and sulfoxide forms during nanoLC-MS/MS analysis. Recently, researchers have started monitoring both normal and sulfoxide forms of the native and SIS tryptic AQUA peptides for quantification assays [54, 62], but as Supplemental Figure 1c shows, the possibility still exists for the normal SIS peptide to contribute to the sulfoxide SIS peak, and for the sulfoxide SIS peptide to further oxidize to the sulfone state, thereby confounding quantification [6365]. This observation drove us to identify and use a peptide lacking chemically reactive residues to use as a signature peptide for LC-MRM quantification of prion protein.

Target peptides from the Glu-C and thermolysin digests were not observed at high intensities in either the direct infusion or online nanoLC analyses (data not shown). In contrast, chymotrypsin generated an intense ion peak at $\mathrm{m} / \mathrm{z}$ 470.7 (2+) corresponding to the doubly charged peptide ion YRPVDQY. We originally targeted RPVDQY as a potential peptide for MRM quantification, but we did not observe ions for this peptide during direct infusion or nanoLC-MS/MS analyses (Supplemental Figure 2). Instead, the predominant ion observed was the doubly charged YRPVDQY ion (one missed cleavage). The reason that production of the missed cleavage form of RPVDQY dominates over that of the fully digested form is unclear. However, the doubly charged YRPVDQY peptide ion met our first criterion for a suitable AQUA peptide since it lacks chemically reactive Cys and Met residues. We assessed the peptide's specificity to prion protein by performing an NCBI BLAST search against nonredundant protein sequences. Results indicated that YRPVDQY is unique to prion protein. We therefore further investigated this peptide.

The candidate AQUA peptide also met our third criterion of sharing homology with a large number of agriculturally important and research model species. Comparison of prion protein primary structure across 46 mammalian species showed that YRPVDQY was conserved in 35 of 46 species [53]. Of the remaining 11 species, six different isoforms of residue 163-169 peptide were observed and only one species did not contain this sequence due to C-terminal truncation. Figure 1 displays the amino acid sequence alignment of 20 prion proteins from mammalian species naturally susceptible to prion disease or serving as important research models. Peptide YRPVDQY resides at amino acid positions 163 to 169 (human PrP numbering). Figure 1 shows that YRPVDQY is common in 16 of the 20 species including rodents (hamster, mouse, rat, voles), cervids (deer, elk, moose), cattle, and goats. Rodents (especially mice and Syrian hamsters) are important models in prion research because mouse genetics can be manipulated to test hypoth- eses, and hamsters have relatively short incubation times and high infectious titers [66]. Cervid CWD is an emerging infectious disease in North America with a rapidly expanding range. BSE in cattle and scrapie in goats are TSEs of agricultural concern, and BSE has spread to humans in the form of variant CJD [16-20]. Discovery that an environmental reservoir of infectivity can contribute to horizontal (animal-to-animal) spread of CWD and scrapie has prompted research to identify sources of infectivity and mechanisms of transmission [4, 7-15]. A LC-MRM assay using the signature peptide YRPVDQY could be implemented in research in these species without the need for assay revalidation. This is not the case for the previously reported peptide VVEQMCTTQYQK (PrP residues 209-220) that is unique to Syrian hamster (Figure 1); revalidation would be required for species with alternative amino acid sequences in this region [54]. Furthermore, use of this peptide is not possible for some species due to C-terminal truncation of the protein [53].

We also investigated whether known species-specific polymorphisms in prion protein could affect this LC-MRM assay. The sequence YRPVDQY is conserved across the cervid, bovid, and rodent species presented in Figure 1. For a polymorphism to affect this assay, the amino acid substitution would have to occur within residues 163 to 169. Substitution of amino acid 169 with a residue other than Phe or Trp would prevent production of the chymotryptic AQUA peptide and would interfere with analysis. Cervids have at least 20 known polymorphisms, but only seven of these alter the primary sequence of $\operatorname{PrP}[5,67]$, and none affect amino acids 163 to 169 or the generation of the chymotryptic peptide. Thirteen polymorphisms have been identified in the bovine Prnp gene with only three affecting the translated protein and none impacting this assay $[67,68]$. In the case of rodents, Syrian hamsters have no known polymorphisms and mice only have two polymorphisms (L108F and T189V), neither of which would interfere with the assay developed here [69]. Although voles have several known polymorphisms, none of them occur between residues 163 and 169 [70]. Therefore, the likelihood that polymorphisms in Prnp gene for these species to hinder the efficacy of the LCMRM method presented here is considered low, making this method generally applicable for a wide range of species.

\section{Determining the Limits of Quantification (LOQ) and Detection (LOD) for YRPVDQY}

The LOQ, LOD, and linear dynamic range for YRPVDQY were empirically determined by LC-MRM on an AB SCIEX 5500 QTRAP. Figure 2 shows the CAD MS/MS spectra of YRPV $\left[{ }^{13} \mathrm{C}_{5},{ }^{15} \mathrm{~N}\right] \mathrm{DQY}$. As expected, b-ions dominate this MS/MS spectrum whereas y-ions dominate MS/MS spectra for tryptic peptides. The y-series dominate tryptic peptide MS/MS spectra because basic Arg and Lys residues reside on the C-terminus resulting in higher signal intensities. In the case of YRPVDQY, chymotryptic digestion produced a 


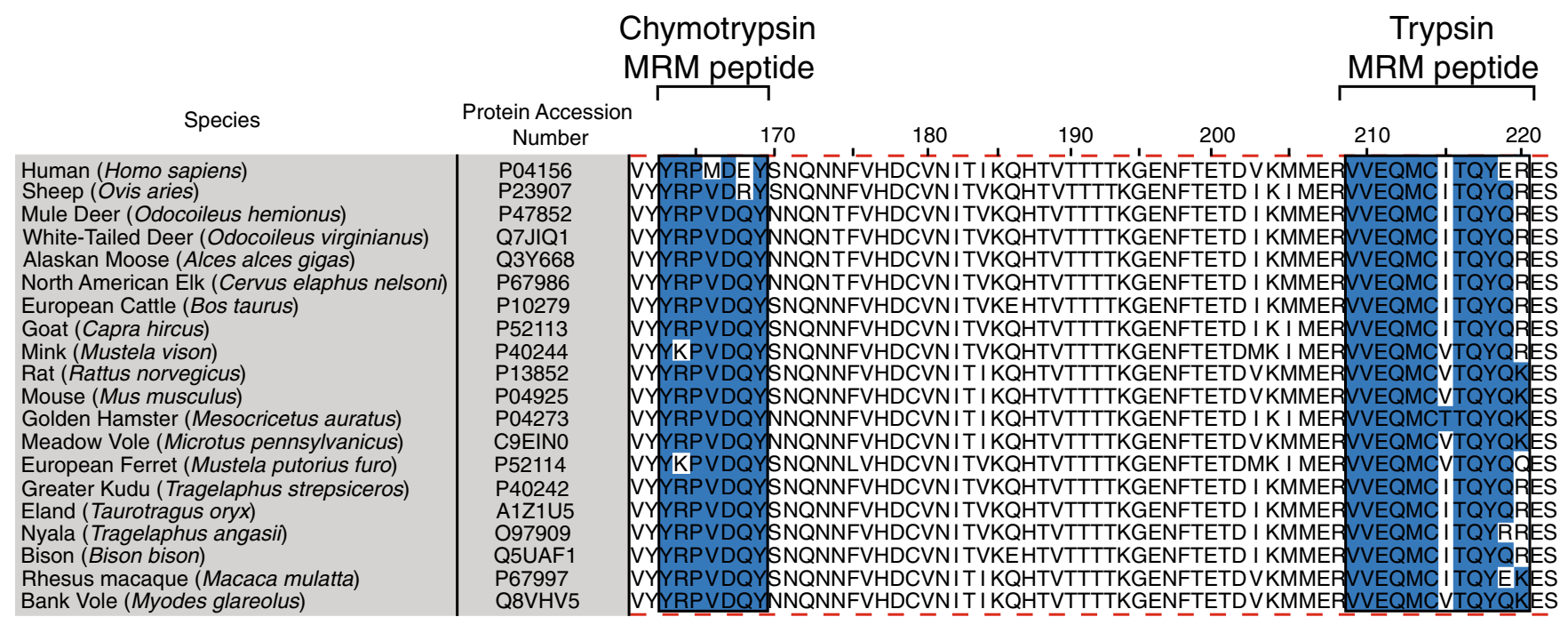

Figure 1. Amino acid alignment of PrP residues 161 to 222 (human PrP numbering) from 20 mammalian species either susceptible to natural prion infection or used as laboratory models. Note that the amino acid sequence for the chymotrypsin MRM peptide is more highly conserved than that for the trypsin-derived MRM peptide. The alignment was performed using the ClustalW algorithm within Jalview software

peptide with an Arg near the N-terminus giving rise to higher intensity b-ions [71]. Instrument and MRM transition settings for SIS peptide YRPVDQY $\mathrm{y}_{1}, \mathrm{~b}_{2}, \mathrm{~b}_{4}, \mathrm{~b}_{5}$, and $\mathrm{b}_{6}$ ion transitions were manually optimized to provide reproducible and highly sensitive measurements (vide supra). After optimization, the $b_{6}$ ion transition was chosen for quantification, and two transitions $\left(b_{5}, y_{1}\right)$ were selected for peptide confirmation (Table 1).

A calibration curve for the optimized $\mathrm{m} / \mathrm{z} 473.7^{+2}$ to $765.3^{+1}$ transition was constructed (Figure $3 \mathrm{a}$ ). The SIS peptide YRPV $\left[{ }^{13} \mathrm{C}_{5},{ }^{15} \mathrm{~N}\right] \mathrm{DQY}$ was serially diluted from 1 $\mathrm{pmol} \cdot \mu \mathrm{L}^{-1}$ to $10 \mathrm{amol} \cdot \mu \mathrm{L}^{-1}$ in $0.2 \mu \mathrm{g} \cdot \mu \mathrm{L}^{-1}$ mouse serum tryptic digest to minimize nonspecific adsorption to the sample vial walls. The SIS peptide $\mathrm{FL}\left[{ }^{13} \mathrm{C}_{6},{ }^{15} \mathrm{~N}_{2}\right] \mathrm{NPWEK}$ served as internal standard and was added to each serial dilution sample at $2.5 \mathrm{fmol} \cdot \mu \mathrm{L}^{-1}$. The mean MRM response value for quintuplicate injections of each calibration standard displayed a linear dynamic range spanning approximately 3.5 orders of magnitude and a LOQ of 80 amol. We collected data for the calibration curve using a mouse serum

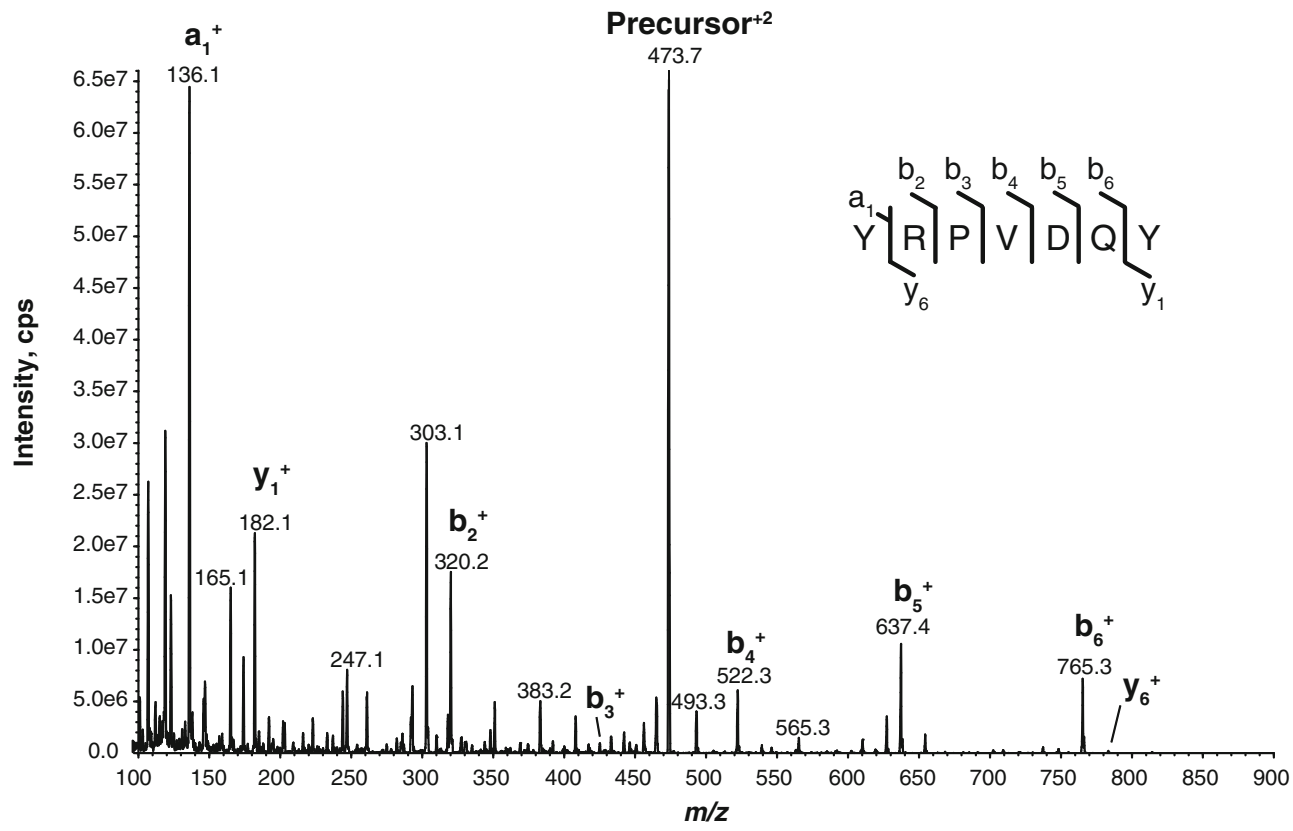

Figure 2. Collisionally activated dissociation (CAD) spectrum of stable isotope-labeled standard peptide YRPVDQY obtained at a collision energy of $20 \mathrm{~V}$ 
Table 1. Optimized MRM Transitions for Selected Chymotryptic Peptides Derived from Bovine and Hamster $\mathrm{PrPP}^{\mathrm{a}}$

\begin{tabular}{|c|c|c|c|c|}
\hline Peptide & Precursor ion $(m / z ; z=+2)$ & Declustering potential (volts) & Collision energy (volts) & Product ion $(m / z ; z=+1)$ \\
\hline \multirow[t]{3}{*}{ RPVDQY (native) } & 389.2 & 63.5 & 17.9 & 596.3 (b5) \\
\hline & 389.2 & 71.0 & 24.1 & $468.3(\mathrm{~b} 4)$ \\
\hline & 389.2 & 71.0 & 17.9 & 182.1 (y1) \\
\hline \multirow{3}{*}{ RPV*DQY (SIS) } & 392.2 & 63.5 & 17.9 & 602.3 (b5) \\
\hline & 392.2 & 71.0 & 24.1 & $474.3(\mathrm{~b} 4)$ \\
\hline & 392.2 & 71.0 & 17.9 & $182.1(\mathrm{y} 1)$ \\
\hline \multirow{3}{*}{ YRPVDQY (native) } & 470.7 & 71.0 & 20.7 & 759.3 (b6) \\
\hline & 470.7 & 71.0 & 26.8 & $631.3(\mathrm{~b} 5)$ \\
\hline & 470.7 & 71.0 & 20.8 & 182.1 (y1) \\
\hline \multirow[t]{3}{*}{ YRPV*DQY (SIS) } & 473.7 & 71.0 & 20.7 & 765.3 (b6) \\
\hline & 473.7 & 71.0 & 26.8 & $637.3(\mathrm{~b} 5)$ \\
\hline & 473.7 & 71.0 & 20.8 & $182.1(\mathrm{y} 1)$ \\
\hline
\end{tabular}

${ }^{\text {a }}$ The italicized/bolded transitions for each peptide indicate the transition used for quantification. The two non-italicized/bolded transitions were used to confirm the peptide's identity. * Indicates the location of the heavy amino acid $\left({ }^{13} \mathrm{C},{ }^{15} \mathrm{~N}\right)$ for SIS peptides

tryptic digest as sample matrix because we observed departures in linearity in the low attomole range $(<100 \mathrm{amol})$ when performing the experiment in a neat matrix (data not shown). We hypothesized that this was due to analyte adsorption to microcentrifuge tubes, pipette tips, and glass sample vials. Additionally, we hypothesized that the addition of a complex sample tryptic digest would mask these adsorption sites without interfering with MRM transitions. We were able to obtain a more accurate and linear calibration curve using this background matrix without affecting the purity of our MRM transitions. Figure $3 \mathrm{a}$ shows the MRM response of seven dilutions of the standards ranging from $80 \mathrm{amol}$ to $200 \mathrm{fmol}$.

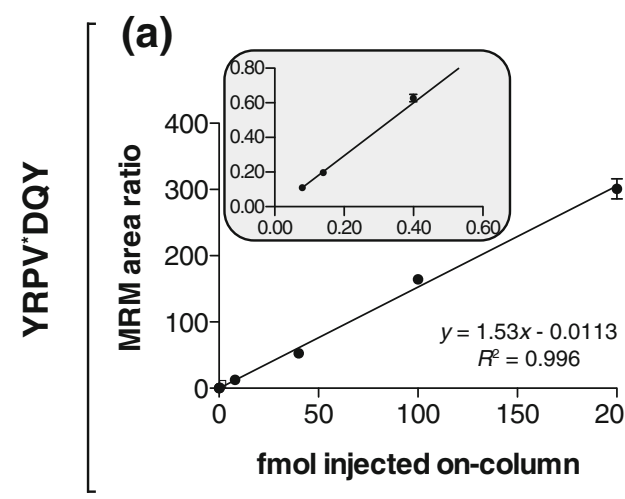

(b)

(c)
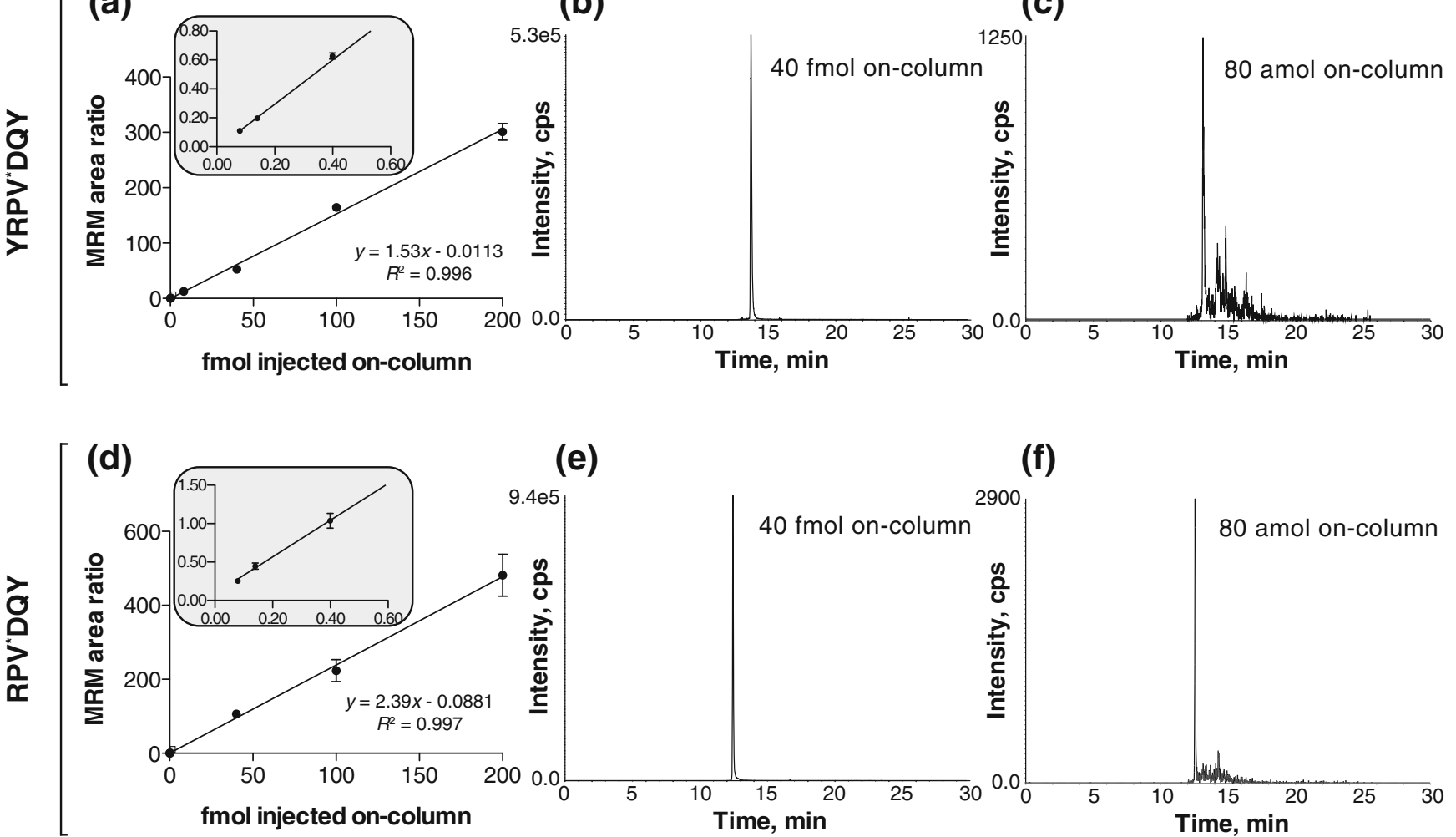

(e)
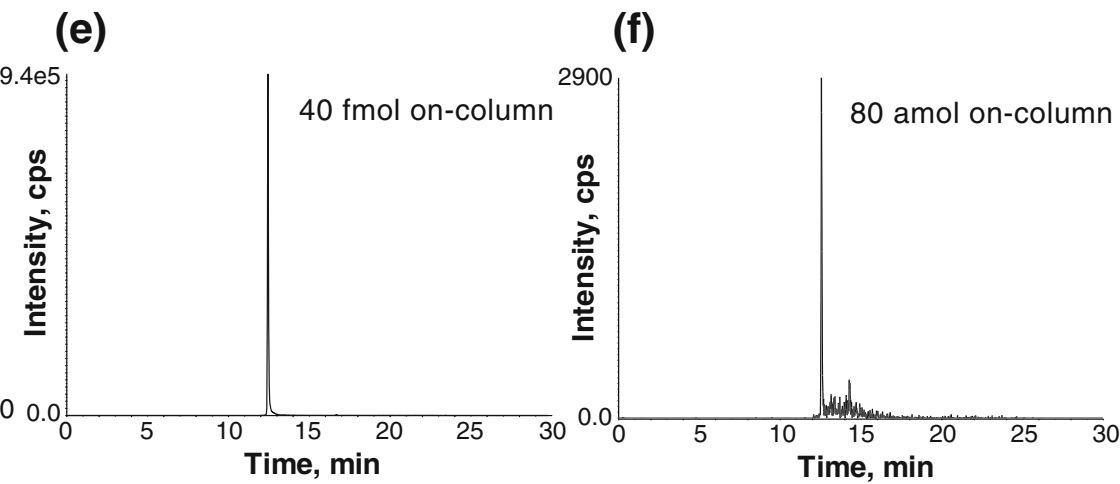

Figure 3. MRM response of chymotryptic stable isotope-labeled standard peptides $Y R P V{ }^{\star} D Q Y$ and $R P V{ }^{\star} D Q Y$ spiked into a $0.2 \mu \mathrm{g} \cdot \mathrm{\mu L}^{-1}$ mouse serum tryptic digest. (a) Linear calibration curve for YRPV*DQY spanning 3.5 orders of magnitude. (b) MRM response for $40 \mathrm{fmol} Y \mathrm{fPV}^{\star} \mathrm{DQY}$ and (c) 80 amol YRPV*DQY. (d) Linear calibration curve for RPVDQY spanning 3.5 orders of magnitude. (e) MRM response for $40 \mathrm{fmol} R P V^{\star} D Q Y$ and (f) 80 amol RPV*DQY. For both peptides, the LOQ was less than 100 amol. Points on the calibration curve correspond to mean values; error bars represent the standard deviation $(n=5)$. The inset is an expansion of the MRM ratios from the three lowest amounts on the calibration curve. * Indicates the location of the heavy amino acid $\left({ }^{13} \mathrm{C},{ }^{15} \mathrm{~N}\right)$ for $\mathrm{SIS}$ peptides 


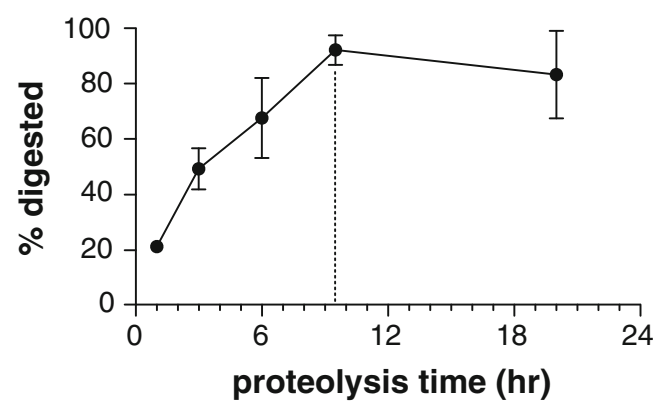

Figure 4. Formation of chymotryptic fragment YRPVDQY from digestion of bovine rPrP. Each point corresponds to the mean of three technical replicates from three separate digests; error bars represent one standard deviation. Native YRPVDQY MRM response was normalized to SIS YRPVDQY MRM response (10 fmol on-column). Dashed line indicates optimal digestion time $(9.5 \mathrm{~h})$

The correlation coefficient for this curve was 0.996 . Figure $3 b$ and c display the chromatographic profiles for $40 \mathrm{fmol}$ and $80 \mathrm{amol}$ injections, respectively. The signal-to-noise ratio (S/ $\mathrm{N}$ ) was calculated using the standard deviation of a blank containing only background matrix $\pm 15 \mathrm{~s}$ of YRPVDQY elution time as an estimate of instrumental/chemical noise. For quintuplicate measurements of $80 \mathrm{amol}$, calculated $\mathrm{S} / \mathrm{N}$ was $\sim 11$; for 40 amol, calculated $\mathrm{S} / \mathrm{N}$ was $\sim 6$. By defining the LOD as the amount of analyte yielding a $\mathrm{S} / \mathrm{N}=3$, we estimate this LC-MRM method can achieve a limit of detection between 20 and $40 \mathrm{amol}$, comparable to that estimated for the tryptic MRM peptide [51]. These results indicate that peptide YRPVDQY meets our second criterion for a suitable AQUA peptide by having a subfemtomole LOD and LOQ.

\section{Optimization of Chymotrypsin Digestion Time}

After establishing that YRPVDQY has a LOQ $<100$ amol and a LOD between 20 and 40 amol, we optimized digestion time using bovine rPrP. Although chymotrypsin cleaves peptide bonds predominantly on the carboxyl side of Tyr,
Phe, and Trp, nonspecific hydrolysis can occur if digestion is conducted for too long [72, 73], making the use of the shortest possible time for complete digestion of $\operatorname{PrP}$ advisable. Based on manufacturer recommendation and previous work by Arsene et al. [74], we determined that the digestion was complete by $9.5 \mathrm{~h}$ using the 5500 QTRAP to measure the native and SIS form of YRPVDQY (Figure 4). In addition, we monitored the digestion using a MALDI autoflex III TOF/TOF and surprisingly observed that after $3 \mathrm{~h}$ of digestion a low intensity singly charged ion peak ( $m / z 777.4)$ appeared (Supplemental Figure 3). This ion peak corresponds with the $\mathrm{m} / \mathrm{z}$ of the fully digested RPVDQY peptide. The MALDI spectra collected during the digestion time optimization experiment and the lack of detectable signal for RPVDQY during the enzyme selection experiment (Supplemental Figure 2) indicate that YRPVDQY is the predominant peptide form produced during chymotrypsin digestion. The reason that chymotrypsin digestion of $\mathrm{rPrP}$ favors production of YRPVDQY over RPVDQY remains unclear. To determine the extent to which YRPVDQY could form RPVDQY we digested $5 \times 10^{-7} \mathrm{M}$ SIS YRPVDQY with chymotrypsin for $9.5 \mathrm{~h}$. The results indicate that only a very small fraction $(\sim 0.1 \%)$ of YRPVDQY was converted to RPVDQY during digestion (Supplemental Figure 4). We hypothesize that during digestion a majority of $\mathrm{rPrP}$ forms the missed cleavage peptide YRPVDQY, whereas a small portion of $r P r P$ hydrolyzes as expected from in silico digestion to form the peptide RPVDQY.

To increase the accuracy of the AQUA assay we monitored both RPVDQY and YRPVDQY with SIS peptides in the final assay. We optimized the $\mathrm{b}_{5}, \mathrm{~b}_{4}$, and $\mathrm{y}_{1}$ transitions of RPVDQY using Skyline software to generate a range of DPs and CEs that could be tested in subsequent MRM experiments. The final optimized parameters for YRPVDQY and RPVDQY are listed in Table 1. We note that RPVDQY behaved similarly to YRPVDQY with respect to LOD, LOQ, and linear dynamic range (Figure $3 \mathrm{~d}-\mathrm{f}$ ). The main difference between YRPVDQY

Table 2. Calibration Curve Statistics for YRPVDQY and RPVDQY MRM Quantification Transitions ${ }^{\mathrm{a}}$

\begin{tabular}{|c|c|c|c|c|c|}
\hline Expected amount (fmol) & \# of replicates & Calculated amount (fmol) & Standard deviation & RSD & Accuracy \\
\hline \multicolumn{6}{|l|}{ YRPV*DQY, b6 transition } \\
\hline 0.080 & 5 & 0.080 & 0.002 & 2.0 & 99.5 \\
\hline 0.14 & 5 & 0.14 & 0.007 & 4.9 & 97.5 \\
\hline 0.40 & 5 & 0.42 & 0.01 & 3.4 & 104.7 \\
\hline 8.0 & 5 & 8.4 & 0.3 & 3.3 & 105.4 \\
\hline 40 & 5 & 35 & 2 & 4.6 & 86.6 \\
\hline 100 & 5 & 108 & 2 & 1.9 & 107.8 \\
\hline 200 & 5 & 197 & 10 & 5.2 & 98.5 \\
\hline \multicolumn{6}{|l|}{ RPV*DQY, b5 transition } \\
\hline 0.080 & 5 & 0.069 & 0.007 & 10.6 & 86.5 \\
\hline 0.14 & 5 & 0.15 & 0.02 & 11.1 & 107.6 \\
\hline 0.40 & 5 & 0.40 & 0.04 & 10.3 & 99.7 \\
\hline 40 & 5 & 45 & 5 & 10.3 & 111.7 \\
\hline 100 & 5 & 94 & 12 & 13.0 & 93.5 \\
\hline 200 & 5 & 202 & 24 & 11.6 & 100.9 \\
\hline
\end{tabular}

${ }^{a}$ The RSD and accuracy of each point on the calibration curve are $<15 \%$ of the true value 
and RPVDQY calibration curves is that the relative standard deviation (RSD) for points on RPVDQY curves was higher than that for YRPVDQY (Table 2). This may be attributed to optimizing RPVDQY by testing only the limited number of DPs and CEs suggested by Skyline software. For YRPVDQY, we optimized all transition voltages by directly infusing YRPVDQY into the mass spectrometer. In any case, the RSD for all points on the calibration curves for both SIS peptides were $\leq 15 \%$, which is within suitable limits for a quantification method [75].

\section{Hamster rPrP $90-231$ Quantification by LC-MRM}

We tested the performance of our LC-MRM AQUA method on a chymotryptic digest of known amount of an N-terminally truncated form of Syrian hamster $\operatorname{rPrP}\left(\mathrm{rPrP}^{90-231}\right)$. We used

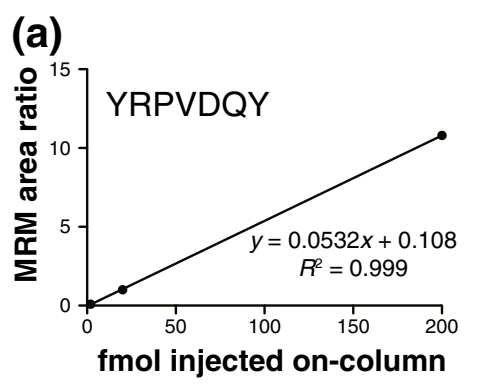

(b)

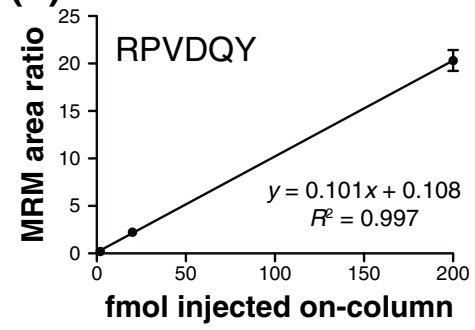

(c)

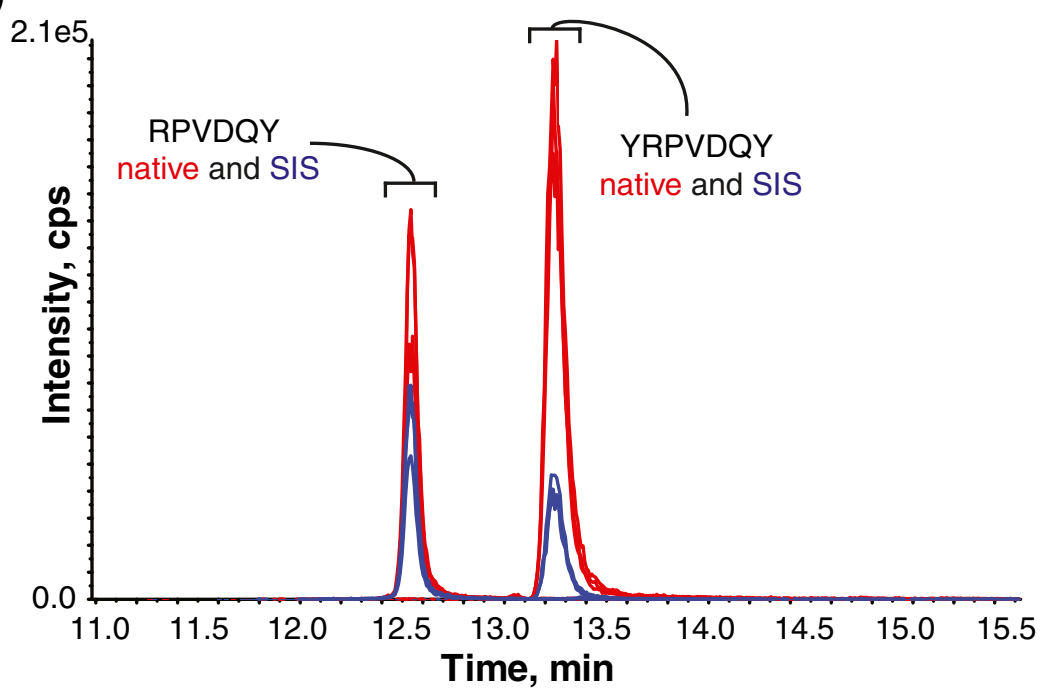

(d)

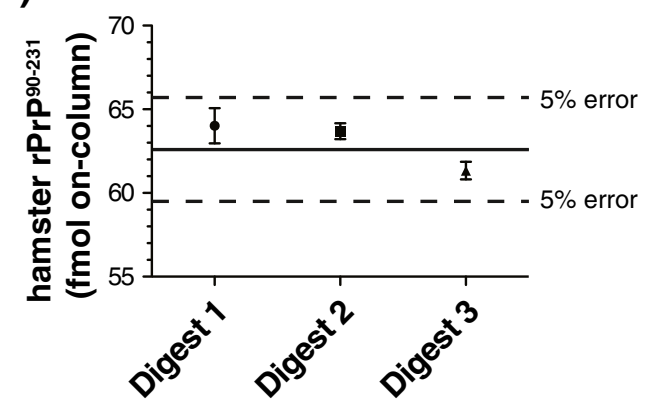

Figure 5. Quantification of hamster $\mathrm{rPrP}^{90-231}$ in a chymotryptic digest using the AQUA approach. (a) and (b) Three-point calibration curves of YRPVDQY and RPVDQY demonstrating a linear relationship over the range of quantification (2 fmol to $200 \mathrm{fmol}$ on-column), respectively. (c) Extracted ion chromatogram of MRM responses for each of the four targeted peptides. Hamster rPrP $\mathrm{Pr}^{931}(2 \mu \mathrm{g})$ was digested with chymotrypsin and diluted such that a $2 \mu \mathrm{L}$ injection yielded $62.7 \mathrm{fmol}$ digest on column. Both SIS internal standards were spiked into each digest to give an amount of $10 \mathrm{fmol}$ on-column. Twelve MRM transitions are displayed (three for each peptide). (d) Quantitative accuracy of rPrP ${ }^{90-231}$ chymotryptic digests. All three $\mathrm{rPrP}$ digests were quantified accurately within $5 \%$ of the native $\mathrm{rPrP}^{90-231}$ amount using the AQUA approach. Each digest was analyzed three times using the 5500 QTRAP. Solid line: amount of native rPrP ${ }^{90-231}$ digest injected on-column $(62.7 \mathrm{fmol}$ or $1.1 \mathrm{nmol} / \mathrm{g}$ ). Dashed line: indicates $5 \%$ error boundary 
$\mathrm{rPrP}^{90-231}$ rather than intact $\mathrm{rPrP}$ because in biological samples PK digestion is used to discriminate $\operatorname{PrP}^{\mathrm{C}}$ from $\operatorname{PrP}^{\mathrm{TSE}}$. Upon proteolysis, $\mathrm{PrP}^{\mathrm{C}}$ is broken up into small peptide fragments, whereas a core of $\operatorname{PrP}^{\mathrm{TSE}}$ (amino acids 90-231) remains intact [21]. After PK digestion, $\operatorname{PrP}^{\mathrm{TSE}}$ would be denatured with $6 \mathrm{M}$ guanidine hydrochloride and then precipitated with methanol to prepare the truncated protein for chymotryptic digestion. Here, three $2-\mu \mathrm{g}$ aliquots of hamster $\mathrm{rPrP}^{90-231}$ were digested with chymotrypsin. Sample preparation was comprised of reduction/alkylation, digestion, addition of SIS peptides, OMIX C18 pipette tip desalting, speedvac concentration, and sample re-suspension/dilution. Recovery experiments were performed to estimate the overall yield of YRPVDQY and RPVDQY after the sample preparation steps. Chymotryptic digests of $\mathrm{PrP}^{90-231}$ ranging from 1 to $100 \mathrm{fmol} \cdot \mu \mathrm{L}^{-1} \mathrm{rPrP}^{90-231}$ were found to have recoveries of $60 \%$ to $81 \%$, respectively. The $2 \mu \mathrm{g}$ digests were diluted so that for a $2.0 \mu \mathrm{L}$ injection the amounts of native RPVDQY and YRPVDQY would sum to approximately 62.7 fmol on-column when measured. SIS peptides for YRPVDQY and RPVDQY were spiked into the digests so the total injected amount of each SIS would be 10 fmol on-column.

Figure $5 \mathrm{a}$ and $\mathrm{b}$ show the calibration curves for YRPVDQY and RPVDQY over the range 2 to $200 \mathrm{fmol}$ on-column. Figure 5c shows the MRM responses for native and SIS AQUA peptides. Comparison of the SIS transitions to the native ion transitions demonstrates that YRPVDQY was the predominant chymotryptic fragment produced during digestion. The average amounts of YRPVDQY and RPVDQY were $44 \pm 1 \mathrm{fmol}$ and $18.6 \pm 0.4 \mathrm{fmol}$ on-column over all three digests, respectively. The total hamster $\mathrm{rPrP}^{90-231}$ amounts calculated on-column for each digest were the following: Digest $1=64.0 \pm 1 \mathrm{fmol}$, Digest $2=63.7 \pm 0.5 \mathrm{fmol}$, Digest $3=61.3 \pm 0.5$ fmol. These values correspond to errors of $2.15 \%, 1.64 \%$, and $2.12 \%$, respectively (Figure $5 \mathrm{~d}$ ). These results underscore the suitability of YRPVDQY and RPVDQY to serve as AQUA peptides for the quantification of $\mathrm{PrP}^{\mathrm{TSE}}$ using a LC-MRM strategy.

\section{Conclusion}

Mass spectrometry represents an attractive alternative to more commonly used assays to measure prions because it offers high-throughput, direct measurement of a protein's signature peptide with subfemtomole sensitivities. Using recombinant forms of the prion protein we demonstrated the utility of a signature peptide produced via chymotrypsin digestion for a LC-MRM AQUA assay. Our new peptides meet the following criteria: (1) lack of chemically active residues (Cys, Met) that can confound assay accuracy, (2) provision of subfemtomole LOD and LOQ, and (3) identical amino acid sequences across multiple commercially and experimentally important mammalian species. Chymotryptic peptides YRPVDQY and RPVDQY do not contain residues susceptible to modification during sample handling and analysis that could hinder quantification experiments. Each provides low attomole LOD and LOQ sensitivities while maintaining a dynamic range over 3.5 orders of magnitude. In addition, both peptides show a high degree of conservation across mammalian species and should not be affected by known polymorphisms. When used to quantify recombinant prion protein, quantification accuracy error was minimal ( $<3 \%)$. The LC-MRM approach presented here is expected to translate well into research studying pathogenic prion protein in a large number of mammalian species. We are currently applying this assay to a variety of mammalian species. In summary, we present an inexpensive, high-throughput, and accurate LC-MRM AQUA method for quantification of prion protein in a variety of economically and research important species. To the authors' knowledge, this is the first report of an LC-MRM AQUA method utilizing signature peptides derived from a non-tryptic peptide.

\section{Acknowledgments}

The authors thank the Analytical Instrumentation Center at the University of Wisconsin-Madison School of Pharmacy for the access to the amaZon ETD ion trap, and Bruker Daltonics for graciously loaning the autoflex III MALDI TOF/TOF mass spectrometer. R.S. acknowledges the NIH-supported Clinical Neuroengineering Training Program Predoctoral Fellowship (NRSA T32 EB011434). G.S. was supported by an NHGRI training grant to the Genomic Sciences Training Program (5T32HG002760). L.M.S. acknowledges support from the Wisconsin Center of Excellence in Genomics Science through NIH/NHGRI grant 1P50HG004952. L.L. acknowledges support from the Wisconsin Alumni Research Foundation and an H. I. Romnes Faculty Research Fellowship. This work was supported by NSF CAREER grant CBET-0547484 (J.A.P.).

\section{References}

1. Prusiner, S.B.: The prion diseases. Brain Pathol. 8, 499-513 (1998)

2. Baeten, L.A., Powers, B.E., Jewell, J.E., Spraker, T.R., Miller, M.W.: A natural case of chronic wasting disease in a free-ranging moose (Alces alces shirasi). J. Wildl. Dis. 43, 309 (2007)

3. Joly, D.O., Ribic, C.A., Langenberg, J.A., Beheler, K., Batha, C.A., Dhuey, B.J., Rolley, R.E., Bartelt, G., Van Deelen, T.R., Samuel, M.D.: Chronic wasting disease in free-ranging Wisconsin white-tailed deer. Emerging Infect. Dis. 9, 599-601 (2003)

4. Mathiason, C.K., Hays, S.A., Powers, J., Hayes-Klug, J., Langenberg, J., Dahmes, S.J., Osborn, D.A., Miller, K.V., Warren, R.J., Mason, G.L., Hoover, E.A.: Infectious prions in preclinical deer and transmission of chronic wasting disease solely by environmental exposure. PLoS One 4, e5916 (2009)

5. Williams, E.S.: Chronic wasting disease. Vet. Pathol. 42, 530-549 (2005)

6. Williams, E.S., Young, S.: Chronic wasting disease of captive mule deer: A spongiform encephalopathy. J. Wildl. Dis. 16, 89-98 (1980)

7. Miller, M., Wild, M., Williams, E.: Epidemiology of chronic wasting disease in captive rocky mountain elk. J. Wildl. Dis. 34, 532 (1998)

8. Miller, M., Williams, E., McCarty, C., Spraker, T., Kreeger, T., Larsen, C., Thorne, E.: Epizootiology of chronic wasting disease in free-ranging cervids in Colorado and Wyoming. J. Wildl. Dis. 36, 676-690 (2000)

9. Miller, M.W., Williams, E.S.: Prion disease: Horizontal prion transmission in mule deer. Nature 425, 35-36 (2003) 
10. Williams, E., Miller, M.: Chronic wasting disease in deer and elk in North America. Rev. Sci. Tech. 21, 305-316 (2002)

11. Georgsson, G., Sigurdarson, S., Brown, P.: Infectious agent of sheep scrapie may persist in the environment for at least 16 years. J. Gen. Virol. 87, 3737-3740 (2006)

12. Johnson, C.J., Phillips, K.E., Schramm, P.T., McKenzie, D., Aiken, J.M., Pedersen, J.A.: Prions adhere to soil minerals and remain infectious. PLoS Pathog. 2, 296-302 (2006)

13. Miller, M.W., Williams, E.S., Hobbs, N.T., Wolfe, L.L.: Environmental sources of prion transmission in mule deer. Emerging Infect. Dis. 10, 1003-1006 (2004)

14. Pálsson, P.: Rida (Scrapie) in Iceland and its epidemiology. In: Prusiner, S.B., Hadlow, W.J. (eds.) Slow Transmissible Diseases of the Nervous System, pp. 357-366. Academic Press, New York (1979)

15. Tamgüney, G., Miller, M.W., Wolfe, L.L., Sirochman, T.M., Glidden, D.V., Palmer, C., Lemus, A., DeArmond, S.J., Prusiner, S.B.: Asymptomatic deer excrete infectious prions in faeces. Nature 461, 529-532 (2009)

16. Michigan Surveillance and Response Plan for Chronic Wasting Disease of Free-Ranging and Privately-Ownned/Captive Cervids. 1-19 (2002)

17. Wisconsin's Chronic Wasting Disease Response Plan: 2010-2025. 1$44(2010)$

18. Belay, E.D., Schonberger, L.B.: The public health impact of prion diseases. Annu. Rev. Publ. Health 26, 191-212 (2005)

19. Joly, D.O., Samuel, M.D., Langenberg, J.A., Blanchong, J.A., Batha, C.A., Rolley, R.E., Keane, D.P., Ribic, C.A.: Spatial epidemiology of chronic wasting disease in Wisconsin white-tailed deer. J. Wildl. Dis. 42, 578-588 (2006)

20. Barria, M.A., Telling, G.C., Gambetti, P., Mastrianni, J.A., Soto, C.: Generation of a new form of human $\mathrm{PrP}^{\mathrm{Sc}}$ in vitro by interspecies transmission from cervid prions. J. Biol. Chem. 286, 7490-7495 (2011)

21. Prusiner, S.B.: Prions. Proc. Nat. Acad. Sci. 95, 13363-13383 (1998)

22. Baldwin, M.A., Stahl, N., Reinders, L.G., Gibson, B.W., Prusiner, S.B., Burlingame, A.L.: Permethylation and tandem mass spectrometry of oligosaccharides having free hexosamine: Analysis of the glycoinositol phospholipid anchor glycan from the scrapie prion protein. Anal. Biochem. 191, 174-182 (1990)

23. Stahl, N., Baldwin, M., Hecker, R., Pan, K., Burlingame, A., Prusiner, S.: Glycosylinositol phospholipid anchors of the scrapie and cellular prion proteins contain sialic acid. Biochemistry 31, 5043-5053 (1992)

24. Stahl, N., Baldwin, M., Teplow, D., Hood, L., Gibson, B., Burlingame, A., Prusiner, S.: Structural studies of the scrapie prion protein using mass spectrometry and amino acid sequencing. Biochemistry 32, 1991$2002(1993)$

25. Stahl, N., Baldwin, M.A., Burlingame, A.L., Prusiner, S.B.: Identification of glycoinositol phospholipid linked and truncated forms of the scrapie prion protein. Biochemistry 29, 8879-8884 (1990)

26. Stahl, N., Baldwin, M.A., Prusiner, S.B.: Electrospray mass spectrometry of the glycosylinositol phospholipid of the scrapie prion protein. Cell Biol. Int. Rep. 15, 853-862 (1991)

27. Stahl, N., Borchelt, D., Hsiao, K., Prusiner, S.: Scrapie prion protein contains a phosphatidylinositol glycolipid. Cell 51, 229-240 (1987)

28. Caughey, B.W., Dong, A., Bhat, K.S., Ernst, D., Hayes, S.F., Caughey, W.S.: Secondary structure analysis of the scrapie-associated protein PrP $27-$ 30 in water by infrared spectroscopy. Biochemistry 30, 7672-7680 (1991)

29. Safar, J., Roller, P.P., Gajdusek, D.C., Gibbs, C.J.: Conformational transitions, dissociation, and unfolding of scrapie amyloid (prion) protein. J. Biol. Chem. 268, 20276-20284 (1993)

30. Prusiner, S.B., Bolton, D.C., Groth, D.F., Bowman, K.A., Cochran, S.P., McKinley, M.P.: Further purification and characterization of scrapie prions. Biochemistry 21, 6942-6950 (1982)

31. Prusiner, S.B., McKinley, M.P., Bowman, K.A., Bolton, D.C., Bendheim, P.E., Groth, D.F., Glenner, G.G.: Scrapie prions aggregate to form amyloidlike birefringent rods. Cell 35, 349-358 (1983)

32. Prusiner, S.B., Cochran, S.P., Groth, D.F., Downey, D.E., Bowman, K.A., Martinez, H.M.: Measurement of the scrapie agent using an incubation time interval assay. Ann. Neurol. 11, 353-358 (1982)

33. Biffiger, K., Zwald, D., Kaufmann, L., Briner, A., Nayki, I., Pürro, M., Bottcher, S., Struckmeyer, T., Schaller, O., Meyer, R., Fatzer, R., Zurbriggen, A., Stack, M., Moser, M., Oesch, B., Kübler, E.: Validation of a luminescence immunoassay for the detection of $\operatorname{PrP}^{\mathrm{Sc}}$ in brain homogenate. J. Virol. Methods 101, 79-84 (2002)

34. Deslys, J.P., Comoy, E., Hawkins, S., Simon, S., Schimmel, H., Wells, G., Grassi, J., Moynagh, J.: Screening slaughtered cattle for BSE. Nature 409, 476-478 (2001)
35. Grassi, J., Comoy, E., Simon, S., Créminon, C., Frobert, Y., Trapmann, S., Schimmel, H., Hawkins, S.A., Moynagh, J., Deslys, J.P., Wells, G.A.: Rapid test for the preclinical postmortem diagnosis of BSE in central nervous system tissue. Vet. Rec. 149, 577-582 (2001)

36. Lee, D.C., Stenland, C.J., Hartwell, R.C., Ford, E.K., Cai, K., Miller, J.L., Gilligan, K.J., Rubenstein, R., Fournel, M., Petteway, S.R.: Monitoring plasma processing steps with a sensitive Western blot assay for the detection of the prion protein. J. Virol. Methods 84, 77-89 (2000)

37. Safar, J., Wille, H., Itri, V., Groth, D., Serban, H., Torchia, M., Cohen, F.E., Prusiner, S.B.: Eight prion strains have $\mathrm{PrP}^{\mathrm{Sc}}$ molecules with different conformations. Nat. Med. 4, 1157-1165 (1998)

38. Wadsworth, J.D., Joiner, S., Hill, A.F., Campbell, T.A., Desbruslais, M., Luthert, P.J., Collinge, J.: Tissue distribution of protease resistant prion protein in variant Creutzfeldt-Jakob disease using a highly sensitive immunoblotting assay. Lancet 358, 171-180 (2001)

39. Zanusso, G., Righetti, P.G., Ferrari, S., Terrin, L., Farinazzo, A., Cardone, F., Pocchiari, M., Rizzuto, N., Monaco, S.: Two-dimensional mapping of three phenotype-associated isoforms of the prion protein in sporadic creutzfeldt-jakob disease. Electrophoresis 23, 347-355 (2002)

40. Safar, J.G., Scott, M., Monaghan, J., Deering, C., Didorenko, S., Vergara, J., Ball, H., Legname, G., Leclerc, E., Solforosi, L., Serban, H., Groth, D., Burton, D.R., Prusiner, S.B., Williamson, R.A.: Measuring prions causing bovine spongiform encephalopathy or chronic wasting disease by immunoassays and transgenic mice. Nat. Biotechnol. 20, 1147-1150 (2002)

41. Castilla, J., Saa, P., Soto, C.: Detection of prions in blood. Nat. Med. 11, 982-985 (2005)

42. Russo, F., Johnson, C.J., Johnson, C.J., McKenzie, D., Aiken, J.M., Pedersen, J.A.: Pathogenic prion protein is degraded by a manganese oxide mineral found in soils. J. Gen. Virol. 90, 275-280 (2009)

43. Saborio, G.P., Permanne, B., Soto, C.: Sensitive detection of pathological prion protein by cyclic amplification of protein misfolding. Nature 411, 810-813 (2001)

44. Cosseddu, G.M., Nonno, R., Vaccari, G., Bucalossi, C., FernandezBorges, N., Di Bari, M.A., Castilla, J., Agrimi, U.: Ultra-efficient $\mathrm{PrP}^{\mathrm{Sc}}$ amplification highlights potentialities and pitfalls of PMCA technology. PLoS Pathog. 7, e1002370 (2011)

45. Gonzalez-Montalban, N., Makarava, N., Ostapchenko, V.G., Savtchenk, R., Alexeeva, I., Rohwer, R.G., Baskakov, I.V.: Highly efficient protein misfolding cyclic amplification. PLoS Pathog. 7, e1001277 (2011)

46. Johnson, C.J., Aiken, J.M., McKenzie, D., Samuel, M.D., Pedersen, J.A.: Highly efficient amplification of chronic wasting disease agent by protein misfolding cyclic amplificatoin with beats (PMCAb). PLoS ONE e35383 (2012)

47. Bian, J., Napier, D., Khaychuck, V., Angers, R.: Cell-based quantification of chronic wasting disease prions. J. Virol. 84, 8322-8326 (2010)

48. Neale, M., Mountjoy, S., Edwards, J.: Infection of cell lines with experimental and natural ovine scrapie agents. J. Virol. 84, 2444-2452 (2010)

49. Gerber, S.A., Rush, J., Stemman, O., Kirschner, M.W., Gygi, S.P.: Absolute quantification of proteins and phosphoproteins from cell lysates by tandem MS. Proc. Nat. Acad. Sci. U.S.A. 100, 6940-6945 (2003)

50. Kirkpatrick, D.S., Gerber, S.A., Gygi, S.P.: The absolute quantification strategy: A general procedure for the quantification of proteins and posttranslational modifications. Methods 35, 265-273 (2005)

51. Onisko, B., Dynin, I., Requena, J.R., Silva, C.J., Erickson, M., Carter, J.M.: Mass spectrometric detection of attomole amounts of the prion protein by nanoLC/MS/MS. J. Am. Soc. Mass Spectrom. 18, 1070-1079 (2007)

52. Onisko, B.C., Silva, C.J., Dynin, I., Erickson, M., Vensel, W.H., Hnasko, R., Requena, J.R., Carter, J.M.: Sensitive, preclinical detection of prions in brain by nanospray liquid chromatography/tandem mass spectrometry. Rapid Commun. Mass Spectrom. 21, 4023-4026 (2007)

53. Wopfner, F., Weidenhöfer, G., Schneider, R., von Brunn, A., Gilch, S., Schwarz, T.F., Werner, T., Schätzl, H.M.: Analysis of 27 mammalian and 9 avian PrPs reveals high conservation of flexible regions of the prion protein. J. Mol. Biol. 289, 1163-1178 (1999)

54. Silva, C.J., Onisko, B.C., Dynin, I., Erickson, M.L., Requena, J.R., Carter, J.M.: Utility of mass spectrometry in the diagnosis of prion diseases. Anal. Chem. 83, 1609-1615 (2011)

55. Kettenbach, A.N., Rush, J., Gerber, S.A.: Absolute quantification of protein and post-translational modification abundance with stable isotope-labeled synthetic peptides. Nat. Prot. 6, 175-186 (2011) 
56. Clamp, M., Cuff, J., Searle, S.M., Barton, G.J.: The jalview java alignment editor. Bioinformatics 20, 426-427 (2004)

57. Waterhouse, A., Procter, J., Martin, D.: Jalview version 2-a multiple sequence alignment editor and analysis workbench. Bioinformatics 25, 1189-1191 (2009)

58. Thompson, J.D., Higgins, D.G., Gibson, T.J.: CLUSTAL W: Improving the sensitivity of progressive multiple sequence alignment through sequence weighting, position-specific gap penalties and weight matrix choice. Nucleic Acids Res. 22, 4673-4680 (1994)

59. MacLean, B., Tomazela, D.M., Shulman, N., Chambers, M., Finney, G.L., Frewen, B., Kern, R., Tabb, D.L., Liebler, D.C., MacCoss, M.J.: Skyline: an open source document editor for creating and analyzing targeted proteomics experiments. Bioinformatics 26, 966-968 (2010)

60. Arnold, U., Rücknagel, K.P., Schierhorn, A., Ulbrich-Hofmann, R.: Thermal unfolding and proteolytic susceptibility of ribonuclease A. Eur. J. Biochem. 237, 862-869 (1996)

61. Silva, C.J., Onisko, B.C., Dynin, I., Erickson, M.L., Vensel, W.H., Requena, J.R., Antaki, E.M., Carter, J.M.: Assessing the role of oxidized methionine at position 213 in the formation of prions in hamsters. Biochemistry 49, 1854-1861 (2010)

62. Canello, T., Engelstein, R., Moshel, O., Xanthopoulos, K., Juanes, M.E., Langeveld, J., Sklaviadis, T., Gasset, M., Gabizon, R.: Methionine sulfoxides on $\operatorname{PrP}^{\mathrm{Sc}}$ : a prion-specific covalent signature. Biochemistry 47, 8866-8873 (2008)

63. Brun, V., Masselon, C., Garin, J., Dupuis, A.: Isotope dilution strategies for absolute quantitative proteomics. J. Proteom. 72, 740-749 (2009)

64. Lange, V., Picotti, P., Domon, B., Aebersold, R.: Selected reaction monitoring for quantitative proteomics: A tutorial. Mol. Syst. Biol. 4, $222(2008)$

65. Pan, S., Aebersold, R., Chen, R., Rush, J., Goodlett, D.R., McIntosh, M.W., Zhang, J., Brentnall, T.A.: Mass spectrometry based targeted protein quantification: Methods and applications. J. Proteome Res. 8, 787-797 (2009)

66. Prusiner, S.B., Safar, J., DeArmond, S.J.: Bioassays of prions. In: Prusiner, S.B. (ed.) Prion Biology and Diseases. Cold Spring Harbor Laboratory Press: pp 143-186 (2003)

67. Heaton, M.P., Leymaster, K.A., Freking, B.A., Hawk, D.A., Smith, T.P., Keele, J.W., Snelling, W.M., Fox, J.M., Chitko-McKown, C.G., Laegreid, W.W.: Prion gene sequence variation within diverse groups of U.S. sheep, beef cattle, and deer. Mamm. Genome 14, 765-777 (2003)

68. Richt, J.A., Hall, S.M.: BSE case associated with prion protein gene mutation. PLoS Pathog. 4, e1000156 (2008)

69. Prusiner, S.B., Scott, M.R.: Genetics of prions. Annu. Rev. Genet. 31, 139-175 (1997)

70. Agrimi, U., Nonno, R., Dell'Omo, G., Di Bari, M.A., Conte, M., Chiappini, B., Esposito, E., Di Guardo, G., Windl, O., Vaccari, G., Lipp, H.P.: Prion protein amino acid determinants of differential susceptibility and molecular feature of prion strains in mice and voles. PLoS Pathog. 4, e1000113 (2008)

71. Tabb, D., Huang, Y., Wysocki, V., Yates, J.: Influence of basic residue content on fragment Ion peak intensities in low-energy-collisioninduced dissociation spectra of peptides. Anal. Chem. 76, 1243-1248 (2004)

72. Blow, D.M.: The structure of chymotrypsin. In: Boyer, P.D. (ed.) The Enzymes, pp. 185-212. Academic Press, New York (1971)

73. Hess, G.P.: Chymotrypsin-chemical properties and catalysis. In: Boyer, P.D. (ed.) The Enzymes, pp. 213-248. Academic Press, New York (1971)

74. Arsene, C.G., Ohlendorf, R., Burkitt, W., Pritchard, C., Henrion, A., O'Connor, G., Bunk, D.M., Güttler, B.: Protein quantification by isotope dilution mass spectrometry of proteolytic fragments: cleavage rate and accuracy. Anal. Chem. 80, 4154-4160 (2008)

75. USFDA: Guidance for industry: Bioanalytical method validation. (2001) 